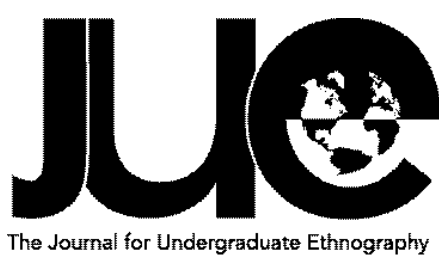

Volume 4 | Issue 2

\title{
Ruptures of War: Shame and Symbolic Violence in Post- Conflict Acholiland
}

\section{David L. Davenport}

University of Richmond, david.davenport@richmond.edu

\section{ABSTRACT}

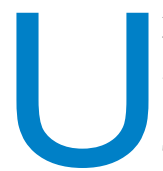

p until 2006, conflict between the Lord's Resistance Army (LRA) and the Ugandan government disrupted lives of people living in northern Uganda. The conflict has challenged ethnic identities, particularly that of the Acholi. Moreover, the disruptions of war have challenged the way my Acholi informants define themselves as human beings and members of society. In the following ethnography, I argue that not only have my informants experienced symbolic violence undermining their sense of honor and worthiness at the hands of the Ugandan government and the LRA, but that the shame they feel after the conflict also commits symbolic violence against themselves. The struggle for honor, dignity, worthiness, and legitimacy has been internalized, and they inhabit psychologically both the position of the dominant and the dominated. For my informants, shame is an undermining force that rattles the way they make sense of their world, affirm their identities, and justify their existence.

Keywords:Acholi (ethnic group), northern Uganda, conflict, shame, symbolic violence 
Conflict in Northern Uganda: A Brief History

For twenty years, war between the Ugandan government and the Lord's Resistance Army ravaged northern Uganda. The conflict has its origins in the tumultuous history of Uganda marked by divisive ethno-national relations preceding and following the country's independence from Britain in 1962 (Doom and Vlassenroot 1999; Karugire 2003; Mazrui 1975). In 1981, Yoweri Museveni, the current president of Uganda, lost the presidential election and subsequently established the National Resistance Army (NRA) in opposition to the national government. After failing to subdue Museveni and the NRA in its stronghold, the Luwero Triangle, President Milton Obote ordered a brutal military operation. The Acholi, along with other ethnic groups of northern Uganda, comprised a significant portion of Obote's armed forces, and consequently, these ethnic groups were blamed for these deaths (Doom and Vlassenroot 1999, 9).

After returning from the war in Luwero, Acholi soldiers failed to integrate socially and cosmologically: other Acholi "viewed [them] as killers" bringing impurity, "immoral[ity]", and evil spirits ${ }^{1}$ into Acholiland (Behrend 1991, 164-65). In response, Alice Lakwena, a young Acholi woman guided by sprits, began the Holy Spirit Movement to purify, integrate, and re-"sanctify" the Acholi and Acholiland (Behrend 1995, 45).

In 1985, Obote was overthrown by his own military, and Acholi General Tito Okello became head of the government. However, no more than six months later in 1986, Museveni and the NRA seized control of Kampala, and Obote's armed forces fled northward to Sudan. Under the rhetoric of rectifying the injustices committed against the people of Luwero, Museveni sent his army northward into Acholiland in pursuit (Doom and Vlassenroot 1999, 9-10). In response, the mission of the Holy Spirit Movement adapted from purifying Achoiland to protecting it (Leggett 2001, 28), and the returning soldiers of Obote joined.

In the end, the movement to defeat the NRA failed, and Alice Lakwena fled Uganda. However, following this defeat, member Joseph Kony sought to revitalize the movement. In 1987, emphasizing a similar "moral rejuvenation" of the Acholi people (Doom and Vlassenroot 1999, 22), Kony established the Lord's Resistance Army (LRA). Overtime, the government counterinsurgent operations to quash the LRA became more and more brutal, and Acholi popular support for the LRA waned. In 1994, 
peace talks began between the LRA and Museveni; however, they quickly collapsed. Kony began castigating the Acholi elders and the Acholi people for not supporting him and the LRA (24).

Following the failure of the peace talks, Kony began to use abduction as a means of recruiting LRA members. These abductions targeted children and youth because they were viewed as blank slates that could be indoctrinated with the principles of Kony which sought to purify Acholiland (25). The LRA also began massacring its own people as well as neighboring ethnic groups in brutal ways that sought to control people through fear (Vinci 2005).

In 1996, Museveni gave the people of northern Uganda forty-eight hours to relocate to designated protection centers, which also served as outposts for the Ugandan army and would later be called camps for Internally Displaced Persons (IDPs). Overpopulated, lacking any infrastructure, and caught between the crosshairs of Museveni's troops and Kony's, these camps became sites of innumerable human rights violations, cultural degeneration, and dehumanization (see Dolan 2009, 159-190).

Ten years later in 2006, after partially successful peace agreements between the LRA and the Ugandan government, the camps were disbanded and people finally permitted to return home. However, by the time I arrived to conduct my fieldwork nearly five years later in 2011 as a study-abroad student (and fledgling anthropologist), many people remained in these camps. For three weeks, I lived in a former IDP camp, and with the help of two key informants and translators, Cynthia and Bosco, I conducted twenty interviews with individuals living in the camp and the surrounding villages. These interviews, along with public lectures given to my study abroad program by members of the community and my experience spending four months in northern Uganda as a student studying conflict and peace-building, form the basis for this ethnography.

\section{Focusing on Shame}

When I had asked Mary to tell me more about the shame she felt, I was expecting a brief answer like many of my informants. Instead, she opened up and bore her shame to me. She explained that "before the war," her father was a farmer, and he wanted his children to study - in fact, she already had an elder brother and sister in secondary school. When she was a little girl in primary school, the "rebels" came (i.e. the LRA), and they killed her father. As a result, "everyone had to look for his own ways." Afterwards, life for the family became very hard, and she had to marry against her will because her family could not provide for her. According to Mary, since her father was not present to ensure her husband respected her, her husband abused her. To escape the domestic violence, Mary returned to her family. In the meantime, her husband took another wife, but soon he wanted Mary to "come back to him." When she returned, her husband had not gone for HIV testing, and she "landed the disease." Mary said that this was the "major shame [she] was having ... because [she is] positive," and "it's been because of the conflict"-because if the war had not taken her father, he would have made sure she found a husband who respected her, and she would not have HIV. Mary concluded that, even though this is a shame to her, "there's nothing [she] can do."

Through her story, Mary reveals that her shame stems from a loss of respect, and she attributes this situation to the conflict which disrupted her family. As a social institution, her family functions to protect her and to ensure she is respected, that her worthiness goes untarnished. However, the conflict divided her family and disturbed this social arrangement: she could not be protected. As a result, she contracted HIV. In the face of these events, Mary feels powerless: "there's nothing [she] can do."

During my fieldwork, Mary was not my only informant who expressed a sense of shame as a result of the war, and this sentiment was common as I asked my informants questions about their lives, livelihoods, and identities after the conflict. This ethnography is my attempt to understand this sense of shame experienced and expressed by my informants.

Shame is the feeling of having lost one's worthiness in the opinion of oneself and/or of society (Pitt-Rivers 1966; Stewart 1994; Wikan 1984). As a result of shame, a person looses a sense of valuing himself and of being valued. In their efforts to rebuild Acholi culture and society after the conflict, many human rights NGOs and cultural institutions are seeking to restore dignity in Acholiland; however, in order to understand how to restore this dignity - this sense of honor, worthiness, or pride-it is important to first understand all of the complex ways in which my informants feel they have lost it.

Ethnographies on conflict in East Africa examining how individuals make sense of their world in the face of violence have generally focused on physical and structural violence (e.g. 
Finnström 2008; Hutchinson 1996). However, the focus of these analyses fails to explain the shame felt by my informants postconflict. Vigh (2006) defines violence as "a relationship between agents whereby at least one of the parties experiences a limitation of his/her agency that is interpreted as illegitimate" (23). In order to understand this shame, an additional form of violence must be considered: symbolic violence. According to Bourdieu (1977), symbolic violence implicates a power relation by which legitimacy and worthiness are vied for via symbolic capital (181). This form of violence seeks to undermine the processes by which worthiness is conferred and to "legitimize" the "authority" of the dominant (192).

In the following ethnography, I will argue that not only have my informants experienced symbolic violence undermining their sense of honor, or worthiness, at the hands of the Ugandan government and the LRA, but that the shame they feel also commits symbolic violence against themselves. For my informants, the struggle for symbolic capital-for honor, dignity, worthiness, and legitimacy-has been internalized, and they inhabit psychologically both the position of the dominant and the dominated. In Acholiland, shame is an undermining force that rattles the way my informants make sense of their world, affirm their identities, and justify their existence.

\section{SHAME AND JUDGMENT: EVALUATIONS OF WORTHINESS}

As we sat on her veranda and watched her four-year-old daughter play in the dirt, Cynthia- a twenty-six-year-old teacher and also my translator-explained how the situation during the conflict was "not good:"

During the conflict, I got hurt, I was traumatized. [....] The situation was not good. I was alarmed. I didn't feel safe. You feel useless and bad-the trauma always disturbs people. [....] Before the war, the Acholi culture used to be very rich in terms of food, in terms of wealth, in terms of moral upbringing, but during the war all these things ... were all destroyed. People got food from World Food Program .... You could say there was an outbreak of famine. People were killed. Other things were destroyed. Animals were taken away .... But [sighing] everything ended up in a mess. [....] Because as the war has ended, people have gone back to their homes, and they want to bring back those days, the nostalgia, the good days when people had their own home and were independent and could care for themselves and their neighbors $\left[\ldots . . .{ }^{2}{ }^{2}\right.$

These feelings of uselessness, trauma, and of a lack of richness which mark Cynthia's livelihood during the conflict and at the present are all manifestations of shame. In their most general sense, they indicate feeling bad, feeling bad about oneself and one's experiences. In addition, all of these feelings arise from a comparison between the way things were in the past before the war and the way things are and have been since the conflict began: for Cynthia, the conflict has led to a loss of "richness" in Acholi life for which many have become "nostalgic." This comparison involves making a judgment in which the present is qualified against the past. However, by comparing her personal experience before the conflict with her experiences since the conflict began, Cynthia also implicates herself in these judgments. She reflects judgments of her present situation inward as judgments of herself and feels personal inadequacy-a feeling Cynthia describes as "uselessness." This feeling began during the conflict and persists in her memory.

In the following section, I will examine how my informants use the Acholiland of the past-with its own principles, practices, and personal experiences-not only to interpret their experiences during the conflict and up until the present, but also to pass judgments on themselves and others. For my informants, the past functions as a habitus, an internalized framework used to interpret and evaluate one's experiences and to direct individual action (Bourdieu 1977, 95). These comparisons evaluating the present against the past are a form of symbolic violence that produce the sense of shame expressed by my informants.

\section{Using the Past to Judge the Present}

For many of my informants, the ability to provide for oneself by "digging" (a colloquialism for cultivating) and raising cattle was very important. For Alice, a sixty-seven-year-old woman, the ability to dig connotes freedom. As we sat on a mat in the middle of her hamlet, she deftly shelled peanuts and explained:

We had a lot of freedom in those days where we could do a lot. We had never experienced war before. There were a lot of changes. We tried to cultivate a lot of thingsmillet, sim sim-in the garden [after the war ended]. But these elephants came and destroyed. And this changed the attitudes of the people, too, towards doing other things. This 
war poisoned the people, and now the people are saying these elephants are coming to destroy people's things.

For Alice, even though the violence of the war has ended, its disruptions persist. As she has tried to restore the "freedom in those days" before the war by planting crops and procuring her own livelihood, she continues to meet obstacles, primarily the one posed by destructive elephants. ${ }^{3}$ Alice incorporates this obstacle to restoring her freedom as one of the many obstacles faced in recovery, and she laments that these challenges have "changed the attitudes of people," who are further discouraged by the destructive elephants. In this statement she is invoking a discourse of laziness prevalent in many of my interviews, especially among the elderly. In brief, this discourse portrays the Acholi people as having become lazy after receiving aid in the camps-a practice which contradicts the purported value of hard work. This discourse uses the Acholi way of life in the past, the Acholi habitus, to judge the lackluster attitudes of individuals after the conflict towards digging and other forms of hard work. Nevertheless, even though Alice expresses a sense of shame over people's present attitudes and frustration over the elephants, Alice perseveres: as she talks about the hardships of digging after the conflict, she continues to grow and shell peanuts. In this way, she actively works to create the freedom she experienced in the past but lost during the war.

For some informants, the conflict not only imposed on freedoms but it robbed people of their humanity. According to Mose Andrew, who is seventy-two years old and knew Acholiland before the war, the conflict disrupted cultural precepts about respecting others. ${ }^{4}$ Describing life in the IDP camp, he said,

Oh! In the camp there was no culture! People just behaved

abnormally ... a lot of raping. Rape was done .... Fighting was also there-Let me say, our behavior was reduced to animals. Before, we respected one another.

Invoking the past-life "before" the conflict, Mose Andrew evaluates camp life. He implies that in these camps people did not respect each other, and he judges people's behavior in the camps as "abnormal" - an aberration from the norm, a norm dictated by the way things were done in the past. For Mose Andrew, the undisturbed Acholi culture before the conflict inculcated dispositions inherent in his current judgment. It is by this perspective, formed by his experiences before the conflict and preserved cognitively, that Mose Andrew judges what he experienced during the war. To convey how contradictory these wartime behaviors were to what is proscribed by his habitus (psychologically located in an undisturbed Acholiland), Mose Andrew compares these behaviors to those of animals. Thus, not only did the conflict disrupt the way people lived their lives, but it compelled behaviors, such as rape, contradictory to the culture's beliefs of acceptable human behavior.

In his statement, Mose Andrew reveals two realms of symbolic violence. The first is experiential. Witnessing "rape" and "fighting" in the camp, Mose Andrew emphasizes how livelihoods marked by violence, disorder, and disrespect led to a loss of human dignity during the conflict. The second is discursive. By stating "our behavior was reduced to animals," Mose Andrew recalls and judges these experiences. He compares his and others' behavior during the conflict to that of animals, and in doing so he delegitimizes the worthiness of himself and others. This discursive act of passing judgment, while acknowledging the delegitimization experienced in the past, recreates this delegitimization in the present. In this way, his judgment commits symbolic violence against himself.

\section{Judging the Self}

Many of my informants expressing shame reflected judgments about experiences and situations inward on themselves to evaluate their own character, dignity, and worthiness. For example, Ojok, considering himself fortunate to have been able to escape Acholiland during the conflict, has returned to his home village in the town and sought political office. He wanted to preserve the camps as memorial sites and ensure younger generations understand what happened during the conflict; however, his idea was controversial. Drawing from the experiences of the members of his community, Ojok explained how some things are too shameful to be shared.

Yes, [I will tell my grandchildren about the conflict,] but during the war here, men were raped. They raped your children, your wife, and then you. And it is a big shame to tell your child. [Your grandchild] will ask, "What were you doing when that was happening?" So some of these things that have happened, [people] do not want them to go ahead: you cannot rape my daughter and then me and then I have to go and tell it to people. I have now lost all of my manhood. I have lost all of my dignity. [Some] people 
just committed suicide because of what took place; they were not killed. Others that haven't committed suicide don't want to tell others that kind of thing. So, not everything will be handed over to the next generation, not everything that took place.

Even though Ojok speaks in general terms and not about his personal experiences, his hypothetical, but realistic, situation exemplifies how circumstances beyond one's control still become indicators of one's character in Acholiland. In an Acholi household, the male figure derives his sense of worthiness from protecting and providing for his family (Kizza et al. 2012, 701703; Odokarach 2011). In Ojok's scenario, the inability to protect his family from rape not only renders the father powerless, but it reflects his lack of worthiness of being a man, his worthiness of possessing the social roles of a father and a husband. The loss itself of worthiness then becomes a source of shame: he is so embarrassed by his own inadequacy and failure to perform his social responsibility that he resorts to suicide, and if he does not resort to suicide, he remains silenced by the shame of this past experience. This shame causes so much personal suffering that he decides not to tell the next generation, his grandchildren, about that experience. Other studies (e.g. Dolan 2009, 191-218; Kizza et al. 2012) indicate that this impairment of masculine identity is systemic in Acholiland, and the subsequent loss of dignity has in fact compelled many Acholi men to commit suicide.

In another interview, Charles, a nineteen-year-old boy studying in secondary school, explained to me why he feels ashamed because of the conflict. He candidly told me,

I can feel ashamed because I myself, I should have not been like this .... I actually lost my father, who was not supposed to die. Otherwise, I would not be in this level [i.e. situation]. If the conflict did not happen, I would not be as I am now.

For Charles, the loss of his father has become a source of shame because his death goes against the natural order of things: being without a father is not how things are "supposed" to be for Charles. His conditional statement points to the conflict as the cause of his current situation and the subsequent shame he experiences. However, the situation is beyond Charles' control. It is merely how he "is." In this way, Charles implies that the circumstances of his existence contradict what is normal. $\mathrm{He}$ judges his own existence to be unnatural, and for this reason he feels shame: his circumstance contradicts the life he is worthy of living, a life where he has not lost his father. ${ }^{5}$

Judgments: A Process of (De)legitimization

In Acholiland, many judgments are being passed. Some of my informants are judging themselves; some are judging others, other Acholi, the government, even the situation itself; and some feel like they are being judged. As the discussion so far reveals, these judgments function as symbolic violence by evaluating the self of an individual and his individual worthiness. However, what is the purpose of these judgments? Are they merely descriptive, intended to evaluate an individual's worthiness? Or are they proscriptive, intended to criticize, sanction, and guide future action? To what extent do these judgments legitimize or de-legitimize the self?

During my interview with Ojok, I asked him how the conflict has changed things. His response began by passing descriptive judgments as he described how the conflict has changed burial practices. However, once he described changes in people's attitudes towards work, his judgments became more proscriptive. He said,

Yes. Things that have changed-you know in the past, say for example, if a person dies, if he is old, say about fifty years old, people will stay for forty days or so before they do the last funeral rites. But now there is no time because so many people die. During those days [before the war], in each clan a person died every six months. But now [during the conflict] it's ten people dying today and tomorrow thirty [....] So what happens is that people devise a way to burry today [...] finishing the funeral there and then. This is a culture that never used to take place.

But then, the war has also brought a lot of attitude change. People nowadays, because of staying [...] for 10 years in the camps without giving production, $[. .$.$] they are$ used to [aid from NGOs], and they still think that somehow somebody is still coming to give them something.

In the beginning, Ojok's tone is complaining, expressing his discontent. He describes how things, like death and disease, were simply beyond people's control. People did not practice proper funeral ceremonies because it was not feasible given the high number of people dying in such a short amount of time. In other words, people changed their behavior because they had to-their behavior was dictated by external factors beyond their control. 
However, as Ojok begins to describe people's attitudes towards working and "producing" for themselves, his tone becomes castigating. He criticizes the people who still want handouts: he criticizes them for not doing something they can do. In Ojok's opinion, people can work because their situation now enables them to.

Ojok's judgments imply that people should adhere to Acholi values and practices as much as it is possible given external constraints. According to Ojok's perspective, while both of these changes are shameful, it is understandable that people were not practicing proper funeral burials because they could not, but it is not understandable that people remain dependent on aid now that the war has ended and circumstance enables them to provide for themselves. This second judgment is overtly proscriptive: it identifies what is "wrong" with people's behavior, shames their behavior, and lays the groundwork for how this behavior can be corrected. On the other hand, the first judgment is more descriptive. It describes the situation, but it does not provide a solution-because the solution was beyond people's present ability. Nevertheless, at the same time, the first descriptive statement is also covertly proscriptive: by referencing proper Acholi values and practices-values and practices that make one honorable-Ojok brings attention to the contradiction between the present way of things and the way things should be done. Thus, while the first judgment does not shame people for not following the ways of the past, invoking the ways of the past keeps them alive and validates them as the way things should be done. Conversely, the second judgment delegitimizes how some people are currently living their lives, bringing their worthiness directly into question.

In brief, the way judgments credit or discredit an individual's worthiness respectively mitigates or exacerbates shame. The shifting around of symbolic capital through such evaluations of worthiness of oneself and of others upholds the habitus of Acholiland before the conflict by discrediting that which contradicts this habitus. However, while these judgments may cognitively preserve the Acholiland of the past and indicate a course of social and cultural redress, judgments that discredit the self are simultaneously forms of symbolic violence which manifest as feelings of shame.

\section{SHAME AND BELONGING: LEGITIMIZING SELF-WORTH VIA THE PERFORMANCE OF IDENTITY}

For many of my informants, the conflict has challenged their sense of belonging and of possessing various social identities. The legitimization of the self is a process underscoring social interaction, and it is by the "presentation" of the self that the self is "credited or discredited" (Goffman 1959, 252-53). This sense of belonging is a measure of self-worth which seeks authentification through the performance identity (cf. Jackson 2001). In Acholiland, clan and ethnic identities are considered something you are born into (ascribed statuses), and these identities are associated with a set of cultural practices and convictions. As a result, while one may always possess one of these memberships, this possession does not imply that one is worthy of belonging. In this manner, failure to perform one's identity calls into question one's worthiness of belonging, one's worthiness of possessing an identity shared by the larger group. Given the great extent to which the conflict disrupted people's lives, these identity performances became difficult, and for some informants, failure to uphold their identities_-and even seeing others failing to do so-has become a source of shame.

In the following section, I will argue that that the conflict disrupted the social mechanisms by which the self is performed and legitimated, and as a result, my informants feel unworthy and ashamed. Furthermore, I will argue that the conflict has had a divergent effect on clan and ethnic identities: whereas the conflict has challenged practices that affirm clan membership and subsequently confer worthiness, the ethnicized ${ }^{6}$ nature of the conflict has challenged Acholi ethnic membership itself as a status worthy of possessing.

\section{Clan Membership: Feeling (Un)Worthy of Belonging}

Feelings of unity, solidarity, and togetherness form the foundation of the clan whose main function is to protect its members, and participation in clan life and ritual is crucial for developing this sense of belonging. However, the conflict significantly disrupted clan practices, and as a result, many informants feel a diminished sense of clan belonging. Dismayed, Cynthia told me,

The conflict has divided people because they are no longer good-hearted. They used to love each other. But during the conflict, elders and parents passed away, and children grew 
up without elders to say, "This is our relative. This is our land ...." So when they go back [home from the camps], [.... there are disputes over land .... So the conflict has really divided people.

Cynthia interprets those who rival over land as "no longer good-hearted." These divisions contradict the notions of unity and protection-of "lov[ing] each other"-which define the clan. She contributes these deficiencies to the absence of "elders" to instruct the young, to inform them that "this is our land." All of these disruptions are the result of "the conflict [which] has divided people." The loss of elders and recurring rivalries over land are two significant challenges to maintaining clan belonging for my informants.

\section{Losing Elders}

Without elders to guide them, many young clan members find themselves at odds, particularly in upholding the morality and practices of the clan. According to Bosco, my translator and key informant, this change made him feel less like a member of his clan:

People prefer leisure time, wealth. And they are not afraid to marry from the same clan-that's after the conflictbecause we lost most of the elders who were the real initiators of the culture system in the clan. So now it's totally lost. People are now diverted to a different direction. So that alone makes me feel I am not [clan name]. ${ }^{\text {? }}$

Without elders to guide them, people are marrying from the same clan. This is so demoralizing for Bosco because marrying within the clan violates clan practice and is considered incest. For many clans in Acholiland, in order to marry, a committee of elders must convene to verify the lineage of each person and make sure they are not from the same clan (Girling 1960, 65$67)$. Without elders to make this verification or to uphold this practice, clan inter-marriage is occurring. For Bosco, intermarriage contradicts the practices of his clan and threatens its cultural unity. Thus, because his clan is not adhering to the same cultural practice in solidarity, Bosco feels like he is not a member of his clan; he feels like he does not belong because his fellow clansmen have "lost" their morals. The conflict has disturbed the cohesion of his clan's practices and challenged the ability of the clan as a social entity to establish a sense of belonging that authenticates Bosco's clan membership.
Land Wrangles

Regarding the second challenge to clan belonging, displaced people are returning home to frequently find that their land before the war is now occupied by others, sometimes even their relatives. Consequently, disputes over land are ubiquitous, and many of these disputes have turned into violent rivalries among clan members or between two different clans (McKibben and Bean 2010, 25-26).

Interestingly, land wrangles can both threaten and reaffirm my informants' sense of clan membership. For John, a chairman of the local government, land wrangles threaten his sense of clan membership. As he sat behind his desk at the office, he explained:

You may become unhappy ... when other clan members are trying to grab your land. Automatically, you become unhappy. You become annoyed because this land belonged to my father. I know you are also my father, but yours is on the other side.

Land wrangles cause frustration between clan members. One person believes that he owns the land-that the land is his, and "belonged to [his] father"-but another clan member disagrees. This causes hardship for the person trying to keep his land because the other person claiming it is extended family. When John states, "I know you are also my father, but yours is on the other side," he reveals that one's biological father and other clan members are both viewed as fathers. Contesting one's father-biological or social-is problematic because the father is a figure of authority and doing so defies the social hierarchy. That fellow clan members are "trying to grab [a clansman's] land" contradicts the solidarity valued by the clan and threatens that person's sense of membership. As a result, he becomes "unhappy" and "annoyed."

On the other hand, for Ojok, resolving land wrangles authenticates his sense of clan belonging. He explains,

When there is some land wrangle taking place, they always come to me and say, "You know, one member of our clan is facing this. Let us go and hear it!" or "Let us go and help him!" or "Let us go and talk about it!"And then I feel really that I am a member of the clan.

For Ojok, settling land disputes makes him feel like a member of his clan, and in explaining this sense of belonging, he refers to the obligation of "helping" one's fellow clansman. When this obligation is invoked, it indicates that he is worthy 
of participating in clan functions. For Ojok, settling land disputes is part of a performance that reinforces his clan identity, authenticates his sense of belonging, and confirms his worthiness as a member of his clan. However, when the clan fails to maintain cohesive values and practices during crisis, this loss of solidarity prevents identity performances from successfully validating the individual clansman's membership and worthiness.

\section{Being Acholi: The Contested Worth of Ethnic Membership}

Examining civil war in southern Sudan, Hutchinson (2001) reveals that ethnic conflict increases divisions between and within ethnic groups and that these divisions accentuating ethnic identity make it a source of suffering (309). Similarly, the ethnicized nature of the conflict in northern Uganda has challenged the value of Acholi identity for my informants: it has become an identity by which many feel stigma and culpability for the conflict. Even though some are still proud to be Acholi, many informants indicated that for them the worthiness of the Acholi identity has become tarnished.

Stereotypes, Stigma, and Culpability: Acholis as rebels

My informants frequently pointed out how other ethnic groups in Uganda have come to associate the Acholi people with the bellicose and brutal actions of the LRA. For example, Charles-whose family fled Acholiland during the conflictexplained how other ethnic groups stereotype Acholis as "rebels."

You know, there are some tribes that distrust this tribe. Most tribes in Uganda, they detest this tribe [the Acholi] because they think we are all rebels. When you go to a different tribe, they may say, "We cannot keep you here, because you are a rebel."

According to Charles, the Acholi are "distrusted" and "detested." Because of this perception, other ethnic groups in Uganda are unwilling to let Acholis stay on their land. They stereotype Acholis as "rebels" who are responsible for the conflict with the government

However, this stereotype is problematic because it assigns culpability for the conflict to all Acholi and overlooks many Acholis' reluctance for the war. According to Mary,

The conflict, it wasn't out of Acholis' intentions-even though it was in Acholi land, of course .... Those who were being abducted into the bush, they were being forced to join the rebels. So they didn't go intentionally.

In 1997, the Human Rights Watch reported that over the course of thirty-six months the LRA had abducted over 8,000 Acholi (Doom and Vlassenroot 1999, 25). Mary points to these forced abductions to demonstrate that the conflict was not the will of many Acholi.

Furthermore, it is important to note that this generalization of the Acholi as all "rebels" plays into the historical marginalization, stereotyping, and scapegoating of the Acholi by other ethnic groups and the Ugandan government. I asked Bob if he thought the conflict would come to be associated with the Acholi people, and he replied:

We will be associated with it because even in 1945, during the Second World War, the Acholi were the majority who went to participate, and we were the ones fighting the war .... Other people, they are the ones who look at us as warriors because they don't have any special power to take us to the bush [i.e. take us to war].

After a century of being the country's military as a result of the British system of "divide and rule" that allocated military responsibilities to the Acholi, many other ethnic groups came to see the Acholi as the warriors of the country (Mazrui 1975). Since independence, Uganda's various presidents have used the historical inclusion of the Acholi in the military and the stereotype of the Acholi as "warriors" to justify invasions and subsequent massacres in northern Uganda (see Atkinson 2011; Doom and Vlassenroot 1999; Finnström 2008; Karugire 2003; and Mazrui 1975). By invoking the historical role of the Acholi as soldiers in World War II, Bob is saying that this conflict will only take the path established by history along which the Acholi are stereotyped as the "warriors" and the "rebels."

The result of these stereotypes and stigma has been an imposition of meanings on Acholi ethnic identity that interferes with my informants' own definitions of Acholi identity. However, in the eyes of some Acholi, they themselves are culpable. According to Agnes, an eighty-nine-year-old woman,

During the conflict here, you could not see anyone here in the village. My husband and two of my sons were killed by the rebels .... What happened in the past was not good, and that is why we are guilty. Kony is Acholi, and we are Acholi, too.

In this statement, Agnes reveals a feeling of guilt, of 
culpability, for the conflict as a result of her ethnic identity. She invokes her shared ethnic identity with Joseph Kony, the leader of the LRA, and it is through her ethnic identity that she feels a responsibility for the violence of the past. The result of stereotypes and stigma assigning culpability to Acholi, as well as the culpability some Acholi feel themselves, has been the transformation of Acholi ethnic identity from a status into an onus.

Demoralization and Failure: The Normalization of the Abnormal

Even though the stereotype that the Acholi are warriors is problematic, it is not totally unfounded. In fact, many of my Acholi informants consider bravery and strength to be defining features of the Acholi. However, the conflict has started to challenge these notions. According to Ojok,

The Acholi were only brave when people were fighting with bows and arrows and spear[s], but now that people are fighting with airplanes and artilleries-and guns that shoot for kilometers-it doesn't even have to be bravery. Because you will just die .... But it has ever been said that Acholis are very brave, that they are warriors. But you can see that they have lost here to war.

Ojok argues that the Acholi are no longer brave because they use modern weapons that "shoot for kilometers." In other words, given the destructiveness and accuracy of modern artillery, there is no bravery in fighting when there is practically guaranteed success without struggle: with these weapons "you will just die." Bravery is having the courage to face your enemy head on and to confront danger-both of which are necessary to kill a lion or an outsider attacking one's homestead, acts epitomizing bravery in Acholi culture (Girling 1960, 102). ${ }^{8}$ Despite these notions of bravery, Ojok admits the Acholi have still "lost" to war. The conflict continued for twenty years between the LRA and the government, longer considering the prior Holy Spirit Movement, and it had a devastating effect on the Acholi people. These notions of failure and cowardice underscore the sense of shame experienced via Acholi ethnic identity.

Furthermore, as the weapon of choice changed from bows, arrows, and spears in Acholiland to guns and other artillery, everyday life has become militarized. Bosco explained that the presence of the gun is now pervasive, and he claimed that the gun also contradicts the Acholi culture:
We no longer follow the culture ... the Acholi way of life .... The conflicts alone brought everyone to get used to the gun. [Before,] people were not so acquainted with guns. But nowadays, you can find a kid of seven or eight month [s] or even a kid of four month[s] —you ask [yourself], "What is that person carrying? It's a gun! Muduku! What does muduku do? It kills ...." But before, people didn't know the gun-the gun was something secret of course. But now, everyone is used to the gun and gunshots. So, we see that the conflict has changed life totally.

Bosco notes that the gun has become normalized: even the practice of children carrying them. According to Hutchinson (1996), the gun possesses a "power that is eerily internal to it" because, unlike a spear, it is not "issue[d] directly from the bones and sinews of the person who hurls" a spear (103). In Acholiland, the power of the gun has become pervasive, and the violence and devastation it wreaks has become normalized: people have become "used to," or desensitized to, the gun and gunshots. This presence of the gun and the normalization of violence contradict Acholi tradition whereby the "gun was something secret" and other weapons-weapons that required bravery like the spearwere used.

\section{Acholi Pride and Shame: A Lived Contradiction}

For some of my informants, the disruptions and suffering caused by the conflict were too much to bear. Multiple informants mentioned they have been ashamed at one point or another to be Acholi. Some even mentioned that during the conflict they wished they could not be Acholi because if they were not Acholi, they would no longer suffer from the violence. This desire to shed one's ethnic identity to escape the conflict blames one's ethnicity for the conflict. At the same time, multiple informants mentioned they were also proud to be Acholi. When I asked Ojok if there had been times when he did not feel like an Acholi, his response illuminated this contradiction:

It has never happened. I'm very proud of Acholi, and I think there is only times when I lament that God-like especially when there was intensive war, and I see how the government side is killing people, and I see how the rebel side is killing the people-and I stand and ask God, "What has Acholi done? What have the Luos done to you?" .... Lamenting. Lamenting and complaining and saying, "God what have 
they done to you? Can't you forgive them?"-But at no moment would I say to you that I regret being an Acholi.

While this contradiction seems to pose a paradox about his ethnic identity, Ojok is actually invoking two different concepts of Acholi identity. When he asks God what the "Acholi" has done, he also refers to them as "Luos." Luo is the general term for the group of Nilotic peoples living in northern Uganda, Southern Sudan, and western Kenya. As Finnström (2008) notes, his Acholi informants use "Luo" when "discuss[ing] their cultural belonging in the context of the wider history of migrations in the region" (36-37). In asking God what the "Luos" have done, Ojok attributes culpability for his suffering to the Acholi as a group of people. However, when he says that he never "regret[s] being an Acholi," Ojok refers not to the Acholi as a group but rather as a concept, an identity. Asking for God's "forgiveness" indicates that Ojok sees the Acholi as a group of people collectively responsible for the suffering each experiences. However, he still takes pride in culturally being an Acholi.

In all, the failure of identity performances to confer worthiness and authenticate the self results in a feeling of shame for my informants. The physical violence of the conflict and other disruptions took on a symbolic dimension whereby the worthiness of ethnic and clan identities were, and continue to be, challenged. My informants interpret this symbolic violence as a personal and collective failure to preserve the virtues of the society into which they were born.

\section{SHAME AND DEHUMANIZATION: ACHOLILAND IN EXISTENTIAL CRISIS}

In addition to being called "rebels", the Acholi acquired another ethnic slur during the time of the conflict: "Ebola." According to Bosco,

During the conflict, some of us were running to Kampala, but we were discriminated [against] .... Ebola was [in northern Uganda] during the time of the conflicts. Most of us, [when we went to Kampala, the capital of Uganda], they would say that this guy is from Gulu [in the North], now they have brought Ebola to us! So people used to say, "Ebola! Ebola!" discriminating us from them. So that really tarnished our minds also. But we still remained Acholi. There was nothing you can do.

Ebola is a highly infectious disease that causes hemorrhagic fever. During the conflict, there were several outbreaks of the disease in the North (see Finnström 2008, 187-89). As a result, when Bosco went to Kampala and people heard he was from the North, they began calling him "Ebola!" This label marks Bosco as an infected person. He is not just a "rebel" who fights against the government, but he is a disease. He is marked as dangerous and infectious simply because of where he comes from. This label has a significant emotional impact on Bosco: he says that this "tarnished" his mind. Stating there was "nothing you can do," Bosco reveals his powerlessness and vulnerability at the hands of other Ugandans who stigmatize him.

"Labels" such as this "deprive [its] victims of identity and community," making it easier to commit violence against them (Kelman and Hamilton 1989, 19). Calling Bosco "Ebola" grants him a less-than-human identity. He has become defined by a disease-one that he does not possess. In the following section, I will argue that humanity is conferred and experienced along ethnic lines in northern Uganda and that the dehumanization of my informants, both by others and by themselves, constitutes symbolic violence.

\section{The Debasement of Self-Worth-Humanity Denied}

For some of my informants, their suffering during the conflict made them question the value of their own lives. The following is an excerpt of my interview with Charles.

DD: What does it mean to be a human being?

$\mathrm{CH}$ : It means just living in the way people can feel safe, when your body is well. You should understand us as being a human body and having humanity .... You get all things which are necessary for you.

DD: Did you feel like a human being during the conflict?

$\mathrm{CH}$ : I did.

DD: Could you tell me more?

$\mathrm{CH}$ : [Laughing] I think you know. When the conflict is in the area, people cannot feel well. So many things happen. Conflict can bring loss of life ... loss of life-Prostitution was also there. And, um ... may lead to some other things .... Some children may remain after the loss of their parents. And some parents may remain after the loss of their children. Things were not supposed to be that way.

Charles acknowledges that human beings possess not only a "body" but also a "humanity," and he identifies "feel[ing] safe" 
and having one's needs met as critical aspects of being human. When I asked him if he felt human during the conflict, he says "yes;" however, he immediately challenges this simple statement when he answers my follow-up question: he identifies practices and experiences during the conflict that upset the way things were "supposed to be," such as death and prostitution. For Charles, his humanity is a lived contradiction: he is human, but during the conflict he experienced events that contradicted his humanity.

When I asked Mose Issaac if the conflict led to a degeneration of the values of hard work and respect we had discussed earlier, he responded,

Yes, the conflict kicked out this feeling that you were a useful being, and it took away your rights as a human. This disappoints you, and you feel bad.

Here, Mose Issaac refers to dehumanization in general: people's rights were "taken away" during the conflict, and he reveals that this dehumanization is felt inwardly: the loss of his rights "disappointed" him, and made him feel "bad." In this manner, experiencing less than human conditions challenged his selfworth, which he measures by his ability to work, his "usefulness." Feeling inadequate and powerless, he also developed a sense of shame: he felt "bad." Thus, the dehumanization he experienced during the war was disempowering and subordinating on both practical and symbolic levels.

In addition to this kind of structural violence, dehumanization was even more poignantly connected to instances of physical violence. According to Ojok,

We had perpetrators among our own, like the LRA rebels. They perpetuated a lot of sufferings, in very many ways: cutting lips, cutting eyes, cutting private parts, killing people in awkward ways, cooking you-even babies. In another way, the government soldiers came by raping what and what. [....] [In the end,] people don't even know who committed atrocities against them.

Ojok draws attention to the bodily mutilations practiced by the LRA and the use of rape by government soldiers on civilians. The physical body symbolizes one's group membership, and as such, it becomes the site of symbolic rituals that affirm or contest this membership (cf. Douglas 2002, 116). The use of bodily mutilation and rape symbolically terminates these social bonds. As a symbol of society, the body also becomes a site for contestations over power, in this case the power of the LRA and the government over the civilian. Anthony Vinci (2005) argues that the LRA's use of bodily mutilation is highly symbolic and communicates messages to the Acholi people that intend to evoke fear in order to augment the "perceived threat" of the LRA and subsequently the power of the LRA. For example, the cutting off of ears and lips signify "beware of informing on the LRA," and rape intends to "humiliate" the "victim ... and his or her family members" (369-70). Moreover, because the body symbolizes an individual's human status, mutilating the body also denigrates the individual's humanity: if his body is not worthy of being physically protected, then his status and dignity as a human being is also not worthy of protection. In brief, the symbolic dimension of physical violence has ramifications on the worthiness and humanity of its victims: it severs social and human bonds, thus exacerbating the divisiveness of conflict.

Internalizing the Discourse of Domination: Being and Becoming Grasshoppers

According to Kelman and Hamilton (1989), "victims must ... be stripped of their human status if they are to be subjected to systematic killing" (19). When the conflict first began and President Museveni marched his troops into Acholiland in 1987 pursuing the soldiers (mainly Acholi) of his predecessor, Milton Obote, he is alleged to have given a denigrating speech. Attempting to dissuade local Acholi from joining the insurgent movement against the state, he compared the Acholi people to grasshoppers in a bottle, and he said that "[the Acholi] will eat each other before they find a way out" (Finnström 2008, 106). While this statement has not been successfully verified (106), it is a story told by multiple informants of mine when explaining how they dislike the government, how ethnic stigmatization has caused them to suffer, and how the conflict denied them humanity.

Many of my informants identified bravery, strength, and their tall and firm bodies as defining characteristics of the Acholi. Comparing the Acholi to small, weak insects-"grasshoppers"directly contradicts this self-concept. Moreover, by removing the Acholi's physical human form, this analogy removes virtues and abilities that are acknowledged upon human status, such as dignity, respect, and agency. Here, the Acholi body is being symbolically denigrated in an assertion of power by the state. Telling the Acholi they will be trapped in a bottle and forced to 
eat their way out does more than belittle the Acholi: it denies them their humanity, and it does so on the basis of their ethnic identity.

Understandably, this analogy is very powerful and full of meaning for my informants. When Bosco, a former member of the LRA, told me he felt a sense of shame after the conflict, I asked him to explain, and he in turn invoked this analogy:

We killed ourselves. It's like when you put the grasshoppers in one bottle. What happens? They bite each other. Have you ever experienced that? You get, like, six grasshoppers, right? Put them in a bottle-you know? ... then see what happens .... They will bite one another .... So we were just killing one, one another. Hmm. So it is a real shame to us ....

Why did that happen? Because even the Acholi themselves who are in the government soldiers, instead of killing the fellow Acholis who are in the bush, why didn't they unite?! And then fight the other tribe?! ... Don't you see? That's a real shame. It's because they were taken advantage [of] by the government. They were being given a lot of money.... to kill one another! .... So that was a real shame to the Acholi -...

And on top of that, we failed even to overthrow the government. So people now ask, "What were you people fighting for? Instead you are just killing one another-and that's another shame. You killed one another, just over some issue between two people: that's Museveni and Kony." So that alone made us kill ourselves .... It is a shame really. We killed ourselves .... That's all I can tell you.

Bosco describes how fighting between Acholis in the LRA and Acholis in the government army, as well as the ultimate failure of the Acholi to "overthrow the government," is shameful. In expressing his sense of shame, Bosco reveals that he has internalized the symbolic violence deployed by the state to subordinate the Acholi: he uses the grasshopper analogy as an interpretive framework by which he comprehends and expresses his own position of subordination, powerlessness, and failure. In order to convey the extent to which the intra-ethnic violence of the conflict defied nature and morality, he equates an Acholi killing another Acholi to cannibalism among grasshoppers. In addition to a failure to unite, this depravity - a loss of not just Acholi virtue, but human virtue-has become a source of shame for Bosco. By deploying this frame of reference, Bosco reinforces the domination of the state by whom this analogy was allegedly first deployed, and this discursive act makes him complicit in his own domination. It is in this vein that shame makes my informants psychologically both the dominant and the dominated.

\section{CONCLUSION}

Mary Douglas (2002) states that "any given culture must confront events which seem to defy its assumptions" (40). In the case of Acholiland, war has not only defied cultural assumptions, but it has led to social and cultural degeneration. New practices- 
such as depending on aid and violence-have been normalized, and changes in the way Acholi conduct their everyday lives have challenged identity performances which are crucial to the authentification of self-worth. The conflict has propagated physical, structural, and symbolic violence as the LRA and the Ugandan government vie to dominate the everyday Acholi. This battle for physical and symbolic domination has left wounded not only bodies, but minds and selves as well, and this contest has called into question my informants' senses of self-worth, of belonging, and of being human. The discrediting of their selves and of their identities has made my informants ashamed to be and possess identities that they were born into. In this sense, shame has become a form of internalized symbolic violence whereby my informants judge their own selves to be unworthy and are felt to be judged by others as unworthy. Finally, the ethnicized nature of the conflict has posed significant challenges in terms of ethnic identity, especially as it has become a category by which humanity and worthiness is conferred and experienced.

Even though war has left Acholiland, the absence of violence does not mean peace has totally returned: shame and discredited identities linger. Thus, the Acholi find themselves "betwixt and between," in a liminal situation, a crisis. In his analysis of social dramas, Victor Turner (1974) writes that

"[c]onflict seems to bring fundamental aspects of society, normally overlaid by the customs and habits of daily intercourse, into frightening prominence" (35), and the case in northern Uganda is no different. The war and the subsequent shame my informants experience has rattled the meanings and practices by which by informants live and interpret their lives.

Even though this ethnography has been challenging to write-and it has likely been challenging at times to readthis topic is one that must be examined. Christopher Taylor (1999), an anthropologist who wrote on the violence that took place in the 1994 Rwandan Genocide, noted that "[h]eroism is eminently more satisfying to write about than human perfidy. Nevertheless, we need to understand human malevolence in all of its ramifications, for it seems that otherwise we are doomed ... to let history repeat itself" (182). In a similar vein, knowing how to heal the wounds of war that the run deep in the minds of my informants is predicated on first understanding these wounds. While this brief paper has attempted to provide an overview of how shame is felt and experienced in post-conflict Acholiland, it is far from comprehensive: the intersections between shame and gender, national identity, and religion-as well as actions being taken to ameliorate this sense of shame-could all use further research.

In focusing on how shame is experienced, as opposed to how shame is combated and overcome, it has not been my intention to portray my informants as only victims of violence. On the contrary, my goal has been to humanize their struggle to maintain dignity as much as possible. Even though it is true my informants are victims, they are also survivors, and more importantly they are everyday people. Granted redress for my informants will not be an easy feat, healing their society, culture, and minds is a task many of them pursue every day as they continue on with their lives. When I asked Rwot Patiko, a clan chief, about the Acholi will go about rebuilding their lives and culture, he replied,

The Acholi is a proud person .... [We are] tall people, strong people .... [When an Acholi goes] hunting and kills a lion - a wild animal- [he is] given a respected name for doing something out of the ordinary: moi. This name means respected .... The Acholi aspire to have that name. To have that name is pride: it is for the greats. 
ACKNOWLEDGMENTS

Throughout the research and writing process, I have been fortunate to have been supported and advised by many people. First, in the United States, I would like to thank my formal and informal advisers at the University of Richmond in the anthropology department: Dr. Jan H. French, for her advice in conducting ethnographic research as well as helping me plan my undergraduate years; Dr. Jennifer Nourse, for her advice in writing this ethnography and overseeing its production; and finally Dr. Hager El Hadidi, with whom my conversations on other projects sparked many ideas for this one. In Uganda, I would like to thank my research advisers and translators, who became friends and mentors. I would also like to thank my host family in Uganda and everyone who welcomed me into their homes and their community during my semester abroad. Thank you for sharing with me your stories and comments, whether in the classroom or in the field. Lastly, I would like to thank my family and friends who have supported me in this endeavor and encouraged me to keep writing. 


\section{REFERENCES}

Atkinson, Ronald. 2011. "Ethnic Stereotypes and Conflict." Lecture given at the School for International Training, Gulu, Uganda, September 13.

Behrend, Heike. 1991. “Is Alice Lakwena a witch? The Holy Spirit Movement and its fight against evil in the north." In Changing Uganda: The Dilemmas of Structural Adjustment and Revolutionary Change, edited by Holger Bernt Hansen and Michael Twaddle, 162-177. London: James Curry.

1999. Alice Lakwena and the Holy Spirits: War in Northern Uganda, 1985-97. Oxford: James Curry.

Bourdieu, Pierre. 1977. Outline of a Theory of Practice. Translated by Richard Nice. Cambridge: Cambridge University Press.

Dolan, Chris. 2009. Social Torture: The Case of Northern Uganda, 1986-2006. New York: Berghahn Books.

Doom, Ruddy and Koen Vlassenroot. 1999. “Kony's Message: A New Koine? The Lord's Resistance Army in Northern Uganda." African Affairs 98(390)(January): 5-36.

Douglas, Mary. 2002. Purity and Danger: An Analysis of the Concepts of Pollution and Taboo. London: Routledge.

Finnström, Sverker. 2008. Living with Bad Surroundings: War, History, and Everyday Moments in Northern Uganda. Durham: Duke University Press.

Girling, F. K. 1960. The Acholi of Uganda. London: Majesty's Stationary Office.

Goffman, Erving. 1959. The Presentation of Self in Everyday Life. New York: Anchor Books.

Hutchinson, Sharon E. 1996. Nuer Dilemmas: Coping with Money, War, and the State. Berkley: University of California Press.

. 2001. “A Curse from God? Religious and political dimension of the post-1991 rise of ethnic violence in South Sudan." Journal of Modern African Studies 39(2)(June): 307-31.

Jackson, John L. 2001. Harlemworld: Doing Race and Class in Contemporary Black America. Chicago: Chicago University Press.

Karugire, Samwiri R. 2003. Roots of Instability in Uganda. 3rd ed. Kampala: Fountain Publishers.

This work is licensed under a Creative Commons AttributionNonCommercialNoDerivs 3.0 Unported License. 
Kelman, Herbert and V. Lee Hamilton. 1989. "The My Lai Massacre: A Military Crime of Obedience." In Crimes of Obedience: Toward a Social Psychology of Authority and Responsibility, edited by Herbert C. Kelman and V. Lee Hamilton, 1-22. Yale University Press.

Kizza, Dorothy, Birthe Loa Knizek, Eugene Kinyanda and Heidi Hjelmeland. 2012. "Men in despair: A qualitative psychological autopsy study of suicide in Northern Uganda."Transcultural Psychiatry 49(5): 696-717. Accessed March 31, 2012. doi: 10.1177/1363461512459490.

Legett, lan. 2001. Uganda: the background, the issues, the people. Oxford: Oxfam.

Mazrui, Ali A. 1975. Soldiers and Kinsmen in Uganda: The Making of a Military Ethnocracy. Beverly Hills: Sage Publications.

McKibben, Gareth and James Bean. 2010. Land or Else: Land-Based Conflict, Vulnerability, and Disintegration in Northern Uganda. Report released by the International Organization for Migration in conjuction with the United Nations Development Programme and Norwegian Refugee Council. Accessed April 16, 2013.

http://reliefweb.int/report/uganda/land-or-else-land-based-conflict-vulnerability-anddisintegration-northern-uganda.

Odokarach, Judith. 2011. "Gender and the Conflict in Northern Uganda." Lecture given at the School for International Training, Gulu, Uganda, September 22.

Pitt-Rivers, Julian. 1966. "Honour and Social Status." In Honour and Shame: The Values of Mediterranean Society. Edited by J. G. Peristiany, 19-77. Chicago: Chicago University Press.

Stewart, Frank Henderson. 1994. Honor. Chicago: Chicago University Press.

Taylor, Christopher C. 1999. Sacrifice as Terror: The Rwandan Genocide of 1994. Oxford: Berg.

Turner, Victor. 1974. Dramas, Fields, and Metaphors: Symbolic Action in Human Society. Ithaca: Cornell University Press.

Vigh, Henrik. 2006. Navigating the Terrains of War: Youth and Soldiering in Guinea Bissau. New York: Berghahn Books.

Vinci, Anthony. 2005. "The Strategic Use of Fear by the Lord's Resistance Army." Small Wars and Insurgencies 16(3)(December): 360-381.

Wikan, Unni. 1984. "Shame and Honour: A Contestable Pair." Man 19(4) (December): 635-52. 


\section{ENDNOTES}

1. Cen, see Finnström 2008, 159-160

2. Throughout the article, separated passages like this one are excerpts from interview transcripts. A regular ellipsis indicates a pause by an informant. An ellipsis in brackets (e.g. [....]) indicates where I have removed text from the original transcript.

3. These elephants were actually a common topic of discussion in the village. Construction of a nearby road was disturbing the elephants' habitat and occasionally forcing them towards the village.

4. Mose [mo-ZAY] is a title for an old man that connotes respect. 5. For more information on the effect the war has had on children and their identities, see Cheney, Kristen. 2007. "'Our Children Have Known Only War': The Predicament of Children and Childhood in Northern Uganda." In Pillars of the Nation: Child Citizens and Ugandan National Development, 167-218. Chicago: University of Chicago Press.

6. I use this term "ethnicized" to refer to the process by which the conflict heightens ethnic tensions.

7. I have removed Bosco's clan name to protect his confidentiality.

8. cf. Ocitti, J.P. 1973. African Indigenous Education, as practised by the Acholi of Uganda. Nairobi: East African Literature Bureau. In Acholi society, hunting "fostered the virtues of endurance, courage, and resourcefulness, the quality of co-operation and the sense of community effort and mutual help" (87). 